\title{
Review Article \\ Processing Challenges and Opportunities of Camel Dairy Products
}

\author{
Tesfemariam Berhe, ${ }^{1,2}$ Eyassu Seifu, ${ }^{3}$ Richard Ipsen, ${ }^{2}$ \\ Mohamed Y. Kurtu, ${ }^{1}$ and Egon Bech Hansen ${ }^{4}$ \\ ${ }^{1}$ School of Animal and Range Sciences, Haramaya University, P.O. Box 138, Dire Dawa, Ethiopia \\ ${ }^{2}$ Department of Food Science, University of Copenhagen, Rolighedsvej 30, 1958 Frederiksberg C, Denmark \\ ${ }^{3}$ Department of Food Science and Technology, Botswana University of Agriculture and Natural Resources, \\ Private Bag 0027, Gaborone, Botswana \\ ${ }^{4}$ Division for Diet, Disease Prevention and Toxicology, National Food Institute, \\ Technical University of Denmark, 2860 Søborg, Denmark
}

Correspondence should be addressed to Tesfemariam Berhe; lucyselam@gmail.com

Received 26 May 2017; Accepted 23 August 2017; Published 3 October 2017

Academic Editor: Salam A. Ibrahim

Copyright (C) 2017 Tesfemariam Berhe et al. This is an open access article distributed under the Creative Commons Attribution License, which permits unrestricted use, distribution, and reproduction in any medium, provided the original work is properly cited.

\begin{abstract}
A review on the challenges and opportunities of processing camel milk into dairy products is provided with an objective of exploring the challenges of processing and assessing the opportunities for developing functional products from camel milk. The gross composition of camel milk is similar to bovine milk. Nonetheless, the relative composition, distribution, and the molecular structure of the milk components are reported to be different. Consequently, manufacturing of camel dairy products such as cheese, yoghurt, or butter using the same technology as for dairy products from bovine milk can result in processing difficulties and products of inferior quality. However, scientific evidence points to the possibility of transforming camel milk into products by optimization of the processing parameters. Additionally, camel milk has traditionally been used for its medicinal values and recent scientific studies confirm that it is a rich source of bioactive, antimicrobial, and antioxidant substances. The current literature concerning product design and functional potential of camel milk is fragmented in terms of time, place, and depth of the research. Therefore, it is essential to understand the fundamental features of camel milk and initiate detailed multidisciplinary research to fully explore and utilize its functional and technological properties.
\end{abstract}

\section{Introduction}

In many countries, especially the dry zones of Sub-Saharan Africa, camels (Camelus dromedarius) play a significant role in the lifestyle of many communities owing to their adaptation to the hostile climatic conditions by providing milk, meat, and transportation. Phenotypic characterization indicated that camels are physiologically, anatomically, and behaviorally adapted to the desert environment. Recent genomic study on the camelid family revealed that the animals carry genetically adapted and evolved genes for desert adaptation such as fat metabolism, osmoregulation, heat stress response, ultraviolet radiation, and choking dust [1]. The genus Camelus consists of two different species that live in vast pastoral areas: Camelus dromedarius, the one-humped camel, which mainly lives in the desert areas of Africa/Middle East, and Camelus bactrianus, the two-humped camel that mainly lives in the cooler dry areas of Asia. More than half of the world's 28 million camel population (old and new world camel) are found in the East African countries, namely, Somalia, Sudan, Ethiopia, and Kenya [2]. Nowadays, the camel is becoming the subject of increasing scientific and commercial interest since climate change is already influencing traditional cattle productivity and the camel is an exceptional animal capable of surviving in the hostile climatic conditions.

Camel milk is composed of lactose, fat, and protein in roughly the same proportion as bovine milk (Table 1). 
TABLE 1: Proximate composition of camel milk compared to milk of other species.

\begin{tabular}{lccccc}
\hline Species & Total solids (\%) & Fat (\%) & Protein (\%) & Lactose (\%) & Ash (\%) \\
\hline${ }^{\mathrm{a}}$ Camel & 12.0 & 3.5 & 3.1 & 4.4 & 4.8 \\
b Bovine & 12.7 & 3.7 & 3.4 & 4.1 & 0.7 \\
${ }^{\mathrm{b}}$ Caprine & 12.3 & 4.5 & 2.9 & 4.8 & 0.8 \\
${ }^{\mathrm{b}}$ Ovine & 19.3 & 7.4 & 4.5 & 1.0 \\
b Human & 12.2 & 3.8 & 1.0 & 7.0 \\
\hline
\end{tabular}

Sources. ${ }^{\mathrm{a}} \mathrm{Al}$ haj and $\mathrm{Al} \mathrm{Kanhal} \mathrm{[17];}{ }^{\mathrm{b}}$ Fox et al. [18].

However, their relative composition, distribution, and the molecular structures of the milk components are different. Proteomic analysis of whey proteins of camel, cow, buffalo, goat, and yak milk has revealed that camel milk whey proteins are hierarchically clustered differently than those from the other species [3].

It is commonly claimed that camel milk is difficult to process into products and is only suitable for drinking as fresh or sour milk. But, currently, the possibility of producing various products from camel milk including soft cheese $[4,5]$, yoghurt [6], and butter [7, 8] has been reported. Also, camel milk has traditionally been recognized for its medicinal values and experimental results indicate that camel milk has antiallergic, antimicrobial, and antidiabetic properties $[9,10]$. The objective of this review is to summarize the processing technologies and functional potential of camel milk. Comparison is made with bovine milk, unless otherwise mentioned.

\section{The Challenges of Processing Camel Milk}

The mean gross chemical composition of camel milk is $3.5 \%$ fat, $3.1 \%$ protein, $4.4 \%$ lactose, $0.8 \%$ ash, and $12 \%$ total solids, which is comparable to bovine milk (Table 1 ). However, their relative composition, distribution, and the molecular structures of the milk proteins (Tables 2 and 3) and fatty acids (Table 4) are reported to be different.

2.1. Processing of Cheese. Processing camel milk into cheese is difficult and has even been considered as impossible [11]. The relative distribution and amino-acid composition of camel milk caseins are different from bovine milk. Camel milk casein has high beta casein $(\beta-\mathrm{CN})$ (65\% versus $39 \%)$, low alpha $S_{1}$-casein $\left(\alpha_{\mathrm{s} 1}-\mathrm{CN}\right)(22 \%$ versus $38 \%)$, and low kappa casein $(\kappa-\mathrm{CN})(3.5 \%$ versus $13 \%)$ as compared to bovine milk caseins (Table 2). Moreover, the camel milk caseins have low homology to bovine milk caseins, being 39\% for $\alpha_{\mathrm{s} 1}-\mathrm{CN}$, $64 \%$ for $\beta-\mathrm{CN}, 56 \%$ for $\alpha_{\mathrm{s} 2}-\mathrm{CN}$, and $56 \%$ for $\kappa-\mathrm{CN}$ [12]. The chymosin cleavage site of camel milk k-CN was found at the $\mathrm{Phe}^{97}-\mathrm{Ile}^{98}$ amino-acid sequence site, whereas the hydrolysis site in bovine milk is $\mathrm{Phe}^{105}-\mathrm{Met}^{106}$ [12]. Thus, the amount of $\kappa-\mathrm{CN}$ in camel milk is relatively small and coagulation of milk in cheese making is typically achieved by enzymatic hydrolysis of $\kappa-\mathrm{CN}$ at the surface of casein micelles.

Alpha-lactalbumin ( $\alpha$-LA) is the major protein in the camel and human milk whey protein group and $\beta$ lactoglobulin $(\beta-\mathrm{LG})$ is absent from camel and human milk
(Table 3). Camel milk has been reported to contain higher whey protein to casein ration compared to bovine milk which is responsible for a soft and easily digestible curd in the gastrointestinal tract [13]. Camel milk casein has large micelle size with an average diameter of 380 versus 150, 260, and $180 \mathrm{~nm}$ compared to bovine, caprine, and ovine milk, respectively [14]. Smaller casein micelles have been reported to improve the gelation properties of bovine milk [15]. Thus, the lower amount of $\mathrm{k}-\mathrm{CN}$, the high ratio of whey protein to casein, and the larger micelle size in camel milk are reported reasons for the difficulty of cheese making. These properties result in formation of a less firm coagulum and lower yield during cheese processing. Such low efficiency of cheese processing trials is reported by Bornaz et al. [14] and Konuspayeva et al. [16].

2.2. Processing of Butter. The fat content of camel milk ranges from 1.2 to $6.4 \%$ [31], which is comparable to that of bovine milk. Nevertheless, butter is not a traditional product made from camel milk and is difficult to produce by using the same technology of production as for butter from bovine milk. The somewhat higher melting point $[7,8]$ of camel milk fat $\left(41-43^{\circ} \mathrm{C}\right)$ makes it difficult to churn the cream at temperatures $10-14^{\circ} \mathrm{C}$, which is the optimum churning temperature for bovine milk. Processing of camel milk into butter is also difficult because camel milk shows little tendency to cream up due to deficiency of the protein agglutinin, small fat globule size, and a thicker fat globular membrane [32]. Camel milk is reported to have a higher proportion of long chain fatty acids and a lower amount of short chain fatty acids (Table 4). The high melting point of camel milk butter can be attributed to the high proportion of long chain fatty acids in the fatty acid profile.

However, butter can be made from camel milk under optimum conditions of churning temperature and agitation method. Berhe et al. [7] reported that vigorous shaking of fermented camel milk in a vertical direction instead of the traditional back- and fro-agitation method at a relatively high churning temperature $\left(22-23^{\circ} \mathrm{C}\right)$ was able to extract butter from camel milk with a fat recovery efficiency of $80 \%$. This method exerts more force to rupture the fat globule membrane and allow the globules to adhere to one another. Farah et al. [8] also reported that camel milk butter was made at churning temperatures between 15 and $36^{\circ} \mathrm{C}$. According to Farah et al. [8], the highest butter fat recovery of $85 \%$ was obtained at a churning temperature of $25^{\circ} \mathrm{C}$. Camel milk butter is prominently white with a more viscous consistency 
TABLE 2: Casein protein distribution of camel, bovine, and human milk.

\begin{tabular}{|c|c|c|c|c|c|c|}
\hline & \multicolumn{3}{|c|}{ Caseins ( $\%$ of total caseins) } & \multicolumn{3}{|c|}{ Amino acid residues } \\
\hline & Camel & Bovine & Human & Camel & Bovine & Human \\
\hline$\alpha_{\mathrm{s} 1}$-casein & $22.0^{\mathrm{a}}$ & $38.0^{\mathrm{b}}$ & $11.8^{\mathrm{c}}$ & $217^{\mathrm{a}}$ & $199^{\mathrm{b}}$ & $170^{\mathrm{d}}$ \\
\hline$\alpha_{\mathrm{s} 2}$-casein & $9.5^{\mathrm{a}}$ & $10.0^{\mathrm{b}}$ & ${ }^{*}$ Absent $^{\mathrm{d}}$ & $178^{\mathrm{a}}$ & $207^{\mathrm{b}}$ & ${ }^{*}$ Absent $^{\mathrm{d}}$ \\
\hline$\beta$-casein & $65.0^{\mathrm{a}}$ & $39.0^{\mathrm{b}}$ & $64.0^{\mathrm{e}}$ & $217^{\mathrm{a}}$ & $209^{\mathrm{b}}$ & $212^{\mathrm{d}}$ \\
\hline$\kappa$-casein & $3.5^{\mathrm{a}}$ & $13.0^{\mathrm{b}}$ & $24.0^{\mathrm{e}}$ & $162^{\mathrm{a}}$ & $169^{\mathrm{b}}$ & $162^{\mathrm{d}}$ \\
\hline Total caseins ( $\mathrm{g} / 100 \mathrm{ml}$ milk) & $2.4^{\mathrm{c}}$ & $2.5^{\mathrm{c}}$ & $0.4^{\mathrm{e}}$ & & & \\
\hline
\end{tabular}

TABLE 3: Whey protein distribution of camel, bovine, and human milk.

\begin{tabular}{|c|c|c|c|c|c|c|}
\hline & \multicolumn{3}{|c|}{ Whey proteins $(\mathrm{g} / \mathrm{L})$ in milk } & \multicolumn{3}{|c|}{ Amino acid residues } \\
\hline & Camel & Bovine & Human & Camel & Bovine & Human \\
\hline$\beta$-Lactoglobulin & ${ }^{*}$ Absent $^{\mathrm{f}}$ & $1.3^{\mathrm{b}}$ & ${ }^{*}$ Absent $^{\mathrm{c}}$ & ${ }^{*}$ Absent $^{\mathrm{f}}$ & $162^{\mathrm{b}}$ & ${ }^{*}$ Absent $^{\mathrm{cg}}$ \\
\hline$\alpha$-Lactalbumin & $5.0^{\mathrm{f}}$ & $1.2^{\mathrm{bc}}$ & $1.8^{\mathrm{cg}}$ & $123^{\mathrm{f}}$ & $123^{\mathrm{b}}$ & $123^{\mathrm{d}}$ \\
\hline Serum albumin & $2.4^{\mathrm{h}}$ & $0.4^{\mathrm{bg}}$ & $0.5^{\mathrm{gc}}$ & - & $582^{\mathrm{b}}$ & $585^{\mathrm{e}}$ \\
\hline Whey acidic protein & $0.16^{\mathrm{f}}$ & - & - & $117^{\mathrm{f}}$ & - & - \\
\hline Lactoferrin & $0.22^{\mathrm{a}}$ & $0.14^{\mathrm{b}}$ & $1.5^{\mathrm{g}}$ & $689^{a}$ & $700^{\mathrm{b}}$ & $700^{c}$ \\
\hline Immunoglobulins & $0.73^{\mathrm{fh}}$ & $0.7^{\mathrm{b}}$ & $1.2^{\mathrm{g}}$ & - & - & - \\
\hline Total whey protein & $9.3^{\mathrm{f}}$ & $7.3^{\mathrm{f}}$ & $7.6^{\mathrm{g}}$ & & & \\
\hline
\end{tabular}

${ }^{*}$ Absent indicates that corresponding coding sequence is absent in genome. Sources. ${ }^{a}$ Kappeler et al. [23], ${ }^{\mathrm{b}}$ Madureira et al. [24] ${ }^{\mathrm{c}}$ Inglingstad et al. [25], ${ }^{\mathrm{d}}$ Findlay and Brew [26], ${ }^{\mathrm{e}}$ Meloun et al. [27], ${ }^{\mathrm{f}}$ El-Agamy [20], ${ }^{\mathrm{g}}$ Malacarne et al. [22], and ${ }^{\mathrm{h}}$ El-Hatmi et al. [28].

TABLE 4: Fatty acid profile of camel milk compared to bovine and human milk (\% fatty acid).

\begin{tabular}{|c|c|c|c|c|}
\hline Carbon number & Fatty acid & Camel milk $^{\mathrm{ab}}$ & Bovine milk $^{\mathrm{abc}}$ & Human milk $^{\mathrm{c}}$ \\
\hline $4: 0$ & Butyric (\%) & 0.8 & 1.4 & 0.1 \\
\hline $6: 0$ & Caproic (\%) & 0.4 & 2.1 & 0.2 \\
\hline $8: 0$ & Caprylic (\%) & 0.3 & 1.7 & 0.3 \\
\hline 10:0 & Capric (\%) & 0.4 & 3.5 & 2.0 \\
\hline 12:0 & Lauric (\%) & 0.7 & 3.9 & 6.8 \\
\hline 14:0 & Myristic (\%) & 11.0 & 12.6 & 10.4 \\
\hline $16: 0$ & Palmitic (\%) & 29.1 & 29.5 & 28.1 \\
\hline 18:0 & Stearic (\%) & 12.4 & 13.3 & 6.9 \\
\hline \multicolumn{5}{|l|}{ Monounsaturated } \\
\hline 14:1 & & 0.5 & - & - \\
\hline $16: 1$ & Palmitoleic (\%) & 10.1 & 1.7 & 3.5 \\
\hline $18: 1$ & Oleic (\%) & 24.5 & 26.3 & 33.6 \\
\hline \multicolumn{5}{|l|}{ Polyunsaturated } \\
\hline $18: 2$ & Linoleic (\%) & 3.1 & 2.9 & 6.4 \\
\hline $18: 3$ & Linolenic (\%) & 1.4 & 1.1 & 1.7 \\
\hline Unsaturated/saturated & & 0.7 & 0.47 & 0.82 \\
\hline Short chain (C4-C14) & & 14.6 & 25.2 & 19.8 \\
\hline Long chain (C16-C20) & & 84.5 & 72.18 & 80.2 \\
\hline
\end{tabular}

${ }^{\mathrm{a}}$ El-Agamy [10], ${ }^{\mathrm{b}}$ El-Agamy [20], and ${ }^{\mathrm{c}}$ Malacarne et al. [22].

compared to bovine milk butter. It is reported that pastoralists in the Sahara region produce small amounts of butter from camel milk and they usually use it for medicinal purposes [11].

2.3. Processing of Yoghurt. Manufacturing of yoghurt or other fermented products from camel milk is reported to be difficult. Dromedary milk coagulum does not have a desirable curd formation and firmness and the curd is instead fragile and heterogeneous and consists of dispersed flakes [33]. The problem with camel milk yoghurt is thus the thin consistency and weak texture of the product. Yoghurt texture is a very important parameter that affects the appearance, mouth feel, 
and overall acceptability. Camel milk has been reported to be not easily fermentable because of its antibacterial properties mainly due to the presence of protective proteins. However, growth of commercial starter cultures in camel milk has been found to be possible. The acidification rate in camel milk was, however, lower than in bovine milk $[34,35]$.

Nevertheless, there are reports that indicate the possibility of yoghurt production from camel milk [36, 37]. Hashim et al. [38] have reported that the firmness of camel milk yoghurt could be improved by supplementation of the milk with gelatin, alginate, and calcium. On the other hand, AlZoreky and Al-Otaibi [39] reported that supplementation of stabilizers to camel milk could not improve the consistency of camel milk yoghurt. Ibrahim [40] suggested that the use of exopolysaccharide producing starter cultures could improve the texture of camel milk yoghurt better than additives. There are also reports that indicate the weak texture of camel milk yoghurt can be improved by mixing of camel milk with milk of other livestock species such as ovine milk [41]. The weak texture and thin consistency of camel milk yoghurt can be attributed to the compositional properties of the milk such as lack of $\beta$-LG and lower amount of k-CN [12], high whey protein to casein ratio [13].

\section{Functional Potential of Camel Dairy Products}

The unique characteristics of camel milk such as its therapeutic potential and absence $\beta$-LG have made it a focus area of research in the fields of health science and nutrition as an antimicrobial, antidiabetic and antihypertensive supplement. Camel milk is showing encouraging results in the treatment of autism, cancer, diabetes, and hepatitis and it is safe for children with bovine milk allergy [42-44].

Camel milk has high vitamin $\mathrm{C}$ and high mineral contents (sodium, potassium, iron, copper, zinc, and magnesium) and can be good nutritional source for the people living in the arid zones $[17,45]$.

3.1. Therapeutic Properties of Camel Milk. Camel milk has been indicated as safe and efficient in improving long-term glycemic control with a significant reduction in the doses of insulin in type 1 diabetic patients $[46,47]$. Agrawal et al. [48] reported that the prevalence of diabetes in the camel milk consuming society of Indian Raica communities was zero. Camel milk is reported to contain insulin-like proteins which is characterized by resistance to gastrointestinal proteolysis, mimics insulin interaction with its receptor, and is easy to absorb into calcium and be encapsulated into lipid nanocapsules [49]. Agrawal et al. [50] have reported that the half cysteine rich protein in camel milk [51] is similar to the insulin family proteins and may be attributed for the glycemic control of camel milk for diabetic patients. Abdulrahman et al. [52] demonstrated that an allosteric effect of camel milk on insulin receptor conformation and activation on the intracellular signaling process may be responsible for the antidiabetic properties of camel milk.
Camel milk was reported to have an antimicrobial effect against Gram-positive and Gram-negative bacteria including Escherichia coli, Listeria monocytogenes, Staphylococcus aureus, and Salmonella typhimurium [53]. This inhibitory activity was reported to be due to presence of higher amounts of protective proteins in camel milk including lysozyme, lactoferrin, lactoperoxidase, and immunoglobulins [23, 53, 54].

Camel milk is reported to have antiviral properties. Immunoglobulin and lactoferrin isolated from camel milk could inhibit the hepatitis $\mathrm{C}$ virus and demonstrated strong signal against its synthetic peptides, while human counterpart failed to do so $[55,56]$. Similarly, camel lactoferrin and lactoperoxidase demonstrated higher inhibition against the entry and direct interaction of hepatitis $\mathrm{C}$ virus to Huh7.5 (hepatocyte-derived carcinoma) and HepG2 (human hepatoma) cells $[55,57,58]$. Korashy et al. [59] investigated that camel milk significantly inhibited HepG2 and MCF7 (human breast) cells proliferation and showed induction of death receptors in both cell lines and oxidative stress mediated mechanisms. It is reported that camel milk could play an important role in decreasing oxidative stress by alteration of enzymatic and nonenzymatic antioxidant molecules as well as thymus activation-regulated chemokine levels which resulted in the improvement of child autism in children [60, 61].

Bioactive peptides derived from milk proteins are of great scientific interests due to their nutritional, technological, and potential health benefits. Bioactive peptides can be enriched or released from milk proteins by the use of selected starter cultures and enzymes and by manipulation of the manufacturing processes such as nanofiltration and encapsulation [62-64]. Bioactive peptides with various biological activities such as antihypertensive, antimicrobial, immunomodulatory, antioxidative, antithrombotic, and antiulcerogenic activities have been reported from milk of camels and other livestock species [9]. Many diseases such as Alzheimer, diabetes, atherosclerosis, rheumatoid arthritis, and cancer result from uncontrolled oxidative stresses by excess of free radicals and other reactive oxygen species present in cellular organism [65-67]. Thus, bioactive peptides derived from milk proteins used as an antioxidants play significant role by preventing the formation of radicals or by scavenging the radicals $[68,69]$.

Camel milk is reported to be a rich source of proteins with potential antimicrobial, angiotensin-converting enzyme (ACE) inhibitory, and antioxidative activities [70-72]. Casein peptides derived from camel milk showed higher antioxidant and ACE-inhibitory activities after enzymatic digestion [7375]. Most ACE-inhibitory and opioid peptide fractions of the fermented milk mainly contained $\beta$-CN derived peptides as precursor molecules [62]. The relatively higher content of $\beta-\mathrm{CN}$ in camel milk may be advantageous from this point of view. Relatively higher digestibility, antimicrobial activity, and antioxidant activity from camel milk $\alpha$-LA and whey protein was reported [76,77]. Moslehishad et al. [72] reported that higher ACE-inhibitory and antioxidant activity was observed in cultured camel milk than bovine milk as a result of structural differences and the presence of higher proline content in camel milk caseins. Homayouni-Tabrizi et al. [71] 
identified two novel antioxidant peptides from camel milk proteins using digestive proteases. Thus, the bioactive properties of camel milk may be responsible for the therapeutic properties of the milk.

\subsection{The Potential of Camel Milk in Infant Formulations.} Infants who are allergic to bovine milk proteins suffer a severe immune response when they ingest nonhuman milk and thus many studies have been done to reduce the allergenicity of bovine milk or to find milks that can substitute bovine milk without producing an allergenic response [78-80]. Human milk is naturally designed to be optimal nutrition for the neonate of the same species. Bovine milk is frequently used to supplement or substitute the human milk for children. Unfortunately, hypersensitivity to bovine milk proteins is a major source of food allergy, which affects primarily infants. The majority of children suffering from bovine milk protein allergy synthesize antibodies primarily against the $\beta$-LG and $\alpha_{\text {s1 }}$-CN [81, 82].

In vitro and in vivo experiments showed that camel milk is hypoallergenic and a promising substitute for children who are allergic to bovine milk [83]. Variations in the aminoacid compositions between bovine milk and human milk are reported to be the problems in feeding bovine milk-based infant formulation (Table 5). Human milk casein pattern revealed that the dominance of $\beta-\mathrm{CN}$ and $\alpha \mathrm{s}_{1}-\mathrm{CN}$ is found in small proportion. Kappeler et al. [12] reported high $\beta-\mathrm{CN}$, lower $\alpha \mathrm{s}_{1}-\mathrm{CN}$, and absence of $\beta$-LG from camel milk. Thus, this tendency indicates the similarity between camel and human milk. Reports indicated that there was no indicator of immunoglobulin E recognition site at the epitopes of camel milk casein and whey proteins indicating the antigenic difference of camel against bovine, goat, and buffalo milk proteins [80, 84]. Restani et al. [84] indicated that the homologies in amino-acid composition or the phylogenetic differences could justify for difference observed in crossreactivity between camel and the other livestock species. $\alpha$ LA is a major whey protein in camel milk and camel $\alpha$-LA hydrolysates showed higher digestibility and more antioxidative activity than bovine $\alpha$-LA [76]. These results showed that the chemical composition of camel milk varies considerably from bovine milk. However, chemical composition of camel milk shows remarkable similarity to human milk showing its potential to substitute bovine milk in infant formulations.

3.3. Storage Stability of Fermented Camel Milk. Fermented milk products are probably developed from the need to extend the shelf life of milk in the absence of cooling facility, their high nutrient contents, and potential health benefits. Traditionally fermented camel milk is the commonly available camel dairy product unlike camel milk cheese, butter, and yoghurt. Fermented camel milk has different names in different parts of the world; Shubat in Turkey, Kazakhstan, and Turkmenistan, Suusac/susa in Kenya and Somalia, Gariss in Sudan, and Dhanaan in Ethiopia. Fermented camel milk is reported to remain relatively stable for a longer time at ambient temperature as a result of the antimicrobial properties of the milk.
TABLE 5: Amino acid composition of camel milk proteins compared with bovine and human milk proteins ( $\mathrm{g} / 100 \mathrm{~g}$ protein).

\begin{tabular}{lccc}
\hline & Camel $^{\mathrm{a}}$ & Bovine $^{\mathrm{b}}$ & Human $^{\mathrm{c}}$ \\
\hline Essential & & & \\
Arginine & 4.0 & 3.7 & 3.3 \\
Histidine & 2.7 & 3.3 & 2.8 \\
Isoleucine & 5.1 & 4.9 & 3.7 \\
Leucine & 9.7 & 9.3 & 9.5 \\
Lysine & 7.2 & 8.1 & 10.1 \\
Methionine & 3.2 & 2.5 & 1.7 \\
Phenylalanine & 5.0 & 4.2 & 3.9 \\
Threonine & 5.7 & 7.3 & 8.3 \\
Tryptophan & 1.2 & 1.4 & 0.5 \\
Valine & 6.7 & 7.6 & 8.2 \\
Nonessential & & & \\
Alanine & 3.0 & 4.0 & 4.2 \\
Aspartic & 7.0 & 7.0 & 6.7 \\
Cysteine & 1.2 & 0.9 & 1.0 \\
Glycine & 1.5 & 2.5 & 2.1 \\
Glutamic & 21.7 & 18.6 & 16.8 \\
Proline & 12.0 & 9.9 & 10.6 \\
Serine & 5.2 & 6.2 & 4.1 \\
Tyrosine & 4.6 & 4.6 & 2.9 \\
\hline Soures. & & &
\end{tabular}

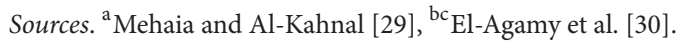

Dhanaan is reported to have higher storage stability. Pastoralists in Eastern Ethiopia responded that the storage stability of Dhanaan is long and it can stay several months when using continuous back slopping, that is, inoculating a new batch of milk with part of a previous batch [85]. Similarly, ElHadi Sulieman et al. [86] reported that the process of removal of the accumulated garris and replacement with fresh camel milk continues for months of time. This might be speculated to the inherent antimicrobial properties of the milk. Potential probiotic lactic acid bacteria strains have been isolated from traditional fermented camel milk and their bacteriocin activities showed inhibitory potential against pathogenic microorganisms $[87,88]$. In addition to lactic acid bacteria, yeasts play significant role in the fermentation of traditional camel dairy products since they have strong proteolytic and lipolytic enzymes [87].

\section{Conclusion}

The main reason for the difficulty of producing products from camel milk is due to the unique structural and functional properties of the milk components. Hence, manufacturing of traditional dairy products using the same technology as for dairy products from bovine milk resulted in processing difficulties. Compositional analyses showed that camel milk is similar to human milk. This indicates the potential of using camel milk in infant formulations to alleviate bovine milk allergy in children. The rich source of bioactive components of camel milk and its compositional properties could be 
attributed to the therapeutic potential of the milk. Information about the processing technologies and functional properties of camel milk is limited. Hence, more detailed study and holistic approach are needed to fully utilize its technological and functional potentials.

\section{Conflicts of Interest}

The authors declare that there are no conflicts of interest regarding the publication of this article.

\section{Acknowledgments}

The authors want to express their great thanks to Danish International Development Agency (Danida) for funding "Haramaya Camel Dairy Project." The partners of the project are the Technical University of Denmark, University of Copenhagen (Denmark), Chr. Hansen A/S (Denmark), and Haramaya University (Ethiopia).

\section{References}

[1] H. Wu, X. Guang, M. B. Al-Fageeh et al., "Camelid genomes reveal evolution and adaptation to desert environments," Nature Communications, vol. 5, article no. 5188, 2014.

[2] FAO stat, 2014. Availlable: http://faostat3.fao.org/, (2017).

[3] Y. Yang, D. Bu, X. Zhao, P. Sun, J. Wang, and L. Zhou, "Proteomic analysis of cow, yak, buffalo, goat and camel milk whey proteins: Quantitative differential expression patterns," Journal of Proteome Research, vol. 12, no. 4, pp. 1660-1667, 2013.

[4] T. Ahmed and R. Kanwal, "Biochemical characteristics of lactic acid producing bacteria and preparation of camel milk cheese by using starter culture," Pakistan Veterinary Journal, vol. 24, no. 2, pp. 87-91, 2004.

[5] M. A. Mehaia, "Manufacture of fresh soft white cheese (Domiati-type) from ultrafiltered goats' milk," Food Chemistry, vol. 79, no. 4, pp. 445-452, 2002.

[6] A. A. Al-Saleh, A. A. M. Metwalli, and E. A. Ismail, "Physicochemical properties of probiotic frozen yoghurt made from camel milk," International Journal of Dairy Technology, vol. 64, no. 4, pp. 557-562, 2011.

[7] T. Berhe, E. Seifu, and M. Y. Kurtu, "Physicochemical properties of butter made from camel milk," International Dairy Journal, vol. 31, no. 2, pp. 51-54, 2013.

[8] Z. Farah, T. Streiff, and M. R. Bachmann, "Manufacture and characterization of camel milk butter," Milchwissenschaft, vol. 44, no. 7, pp. 412-414, 1989.

[9] M. H. A. El-Salam and S. El-Shibiny, "Bioactive peptides of buffalo, camel, goat, sheep, mare, and yak milks and milk products," Food Reviews International, vol. 29, no. 1, pp. 1-23, 2013.

[10] E. I. El-Agamy, "Bioactive Components in Camel Milk," Bioactive Components in Milk and Dairy Products, pp. 159-194, 2009.

[11] R. Yagil, "Camels and camel milk," FAO Animal Production and Health Paper, vol. 26, 69 pages, 1982.

[12] S. Kappeler, Z. Farah, and Z. Puhan, "Sequence analysis of Camelus dromedarius milk caseins," Journal of Dairy Research, vol. 65, no. 2, pp. 209-222, 1998.

[13] S. M. Shamsia, "Nutritional and therapeutic properties of camel and human milks," International Journal of Genetics and Molecular Biology, vol. 1, no. 2, pp. 52-58, 2009.
[14] S. Bornaz, A. Sahli, A. Attalah, and H. Attia, "Physicochemical characteristics and renneting properties of camels' milk: a comparison with goats', ewes' and cows' milks," International Journal of Dairy Technology, vol. 62, no. 4, pp. 505-513, 2009.

[15] M. Glantz, T. G. Devold, G. E. Vegarud, H. Lindmark Månsson, H. Stålhammar, and M. Paulsson, "Importance of casein micelle size and milk composition for milk gelation," Journal of Dairy Science, vol. 93, no. 4, pp. 1444-1451, 2010.

[16] G. Konuspayeva, B. Camier, F. Gaucheron, and B. Faye, "Some parameters to process camel milk into cheese," Emirates Journal of Food and Agriculture, vol. 26, no. 4, pp. 354-358, 2014.

[17] O. A. Al haj and H. A. Al Kanhal, "Compositional, technological and nutritional aspects of dromedary camel milk," International Dairy Journal, vol. 20, no. 12, pp. 811-821, 2010.

[18] P. F. Fox, T. Uniacke-Lowe, P. L. H. McSweeney, and J. A. O'Mahony, "Dairy chemistry and biochemistry, second edition," Dairy Chemistry and Biochemistry, Second Edition, pp. 1584, 2015.

[19] W. Eigel, J. Butler, C. Ernstrom et al., "Nomenclature of proteins of cow's milk: fifth revision," Journal of Dairy Science, vol. 67, no. 8, pp. 1599-1631, 1984.

[20] I. E. El-Agamy, "Camel milk," in Handbook of Milk of NonBovine Mammals, Y. W. Park and G. F. W. Haenlein, Eds., p. 297, 1st edition, 2008.

[21] P. Martin, C. Cebo, and G. Miranda, "Interspecies comparison of milk proteins: quantitative variability and molecular diversity," in Encyclopedia of Dairy Sciences, J. W. Fuquay, P. E. Fox, and., and P. L. H. McSweeney, Eds., pp. 3-821, Elsevier Ltd, 1st edition.

[22] M. Malacarne, F. Martuzzi, A. Summer, and P. Mariani, "Protein and fat composition of mare's milk: Some nutritional remarks with reference to human and cow's milk," International Dairy Journal, vol. 12, no. 11, pp. 869-877, 2002.

[23] S. R. Kappeler, M. Ackermann, Z. Farah, and Z. Puhan, "Sequence analysis of camel (Camelus dromedarius) lactoferrin," International Dairy Journal, vol. 9, no. 7, pp. 481-486, 1999.

[24] A. R. Madureira, C. I. Pereira, A. M. P. Gomes, M. E. Pintado, and F. Xavier Malcata, "Bovine whey proteins - Overview on their main biological properties," Food Research International, vol. 40, no. 10, pp. 1197-1211, 2007.

[25] R. A. Inglingstad, T. G. Devold, E. K. Eriksen et al., "Comparison of the digestion of caseins and whey proteins in equine, bovine, caprine and human milks by human gastrointestinal enzymes," Dairy Science and Technology, vol. 90, no. 5, pp. 549-563, 2010.

[26] J. B. C. Findlay and K. Brew, "The Complete Amino-Acid Sequence of Human $\alpha$-Lactalbumin," European Journal of Biochemistry, vol. 27, no. 1, pp. 65-86, 1972.

[27] B. Meloun, L. Morávek, and V. Kostka, "Complete amino acid sequence of human serum albumin," FEBS Letters, vol. 58, no. 1-2, pp. 134-137, 1975.

[28] H. El-Hatmi, A. Levieux, and D. Levieux, "Camel (Camelus dromedarius) immunoglobulin G, $\alpha$-lactalbumin, serum albumin and lactoferrin in colostrum and milk during the early post partum period," Journal of Dairy Research, vol. 73, no. 3, pp. 288-293, 2006.

[29] M. A. Mehaia and M. A. Al-Kahnal, "Studies on camel and goat milk proteins: nitrogen distribution and amino acid composition," Nutrition Reports International, vol. 39, no. 2, pp. 351-357, 1989.

[30] E. I. El-Agamy, I. A.-S. Zeinab, and Y. Abdel-Kaader, "A comparative study of milk proteins from different species II. Electrophoretic patterns, molecular characterization, amino acid 
composition and immunological relationships," in Proceedings of the 3rd Alexandria Conference of Food Science and Technology, pp. 67-87, 1997.

[31] G. Konuspayeva, B. Faye, and G. Loiseau, "The composition of camel milk: a meta-analysis of the literature data," Journal of Food Composition and Analysis, vol. 22, no. 2, pp. 95-101, 2009.

[32] Z. Farah, camel milk properties, 1st ed. SKAT, Sweden, 1996.

[33] H. Attia, N. Kherouatou, and A. Dhouib, "Dromedary milk lactic acid fermentation: Microbiological and rheological characteristics," Journal of Industrial Microbiology and Biotechnology, vol. 26, no. 5, pp. 263-270, 2001.

[34] H. M. Abu-Tarboush, "Comparison of Associative Growth and Proteolytic Activity of Yogurt Starters in Whole Milk from Camels and Cows," Journal of Dairy Science, vol. 79, no. 3, pp. 366-371, 1996.

[35] T. Berhe, R. Ipsen, E. Seifu, M. Y. Kurtu, M. Eshetu, and E. B. Hansen, "Comparison of the acidification activities of commercial starter cultures in camel and bovine milk," LWTFood Sceince Technol, 2017.

[36] S. K. Ahmed, R. Haroun, and M. O. Eisa, "Banana frozen yoghurt from camel milk," Pakistan Journal of Nutrition, vol. 9, no. 10, pp. 955-956, 2010.

[37] E. A. Eissa, A. E. A. Yagoub, E. E. Babiker, and I. A. Mohamed Ahmed, "Physicochemical, microbiological and sensory characteristics of yoghurt produced from camel milk during storage," Electronic Journal of Environmental, Agricultural and Food Chemistry, vol. 10, no. 6, pp. 2305-2313, 2011.

[38] I. B. Hashim, A. H. Khalil, and H. Habib, "Quality and acceptability of a set-type yogurt made from camel milk," Journal of Dairy Science, vol. 92, no. 3, pp. 857-862, 2009.

[39] N. S. Al-Zoreky and M. M. Al-Otaibi, "Suitability of camel milk for making yogurt," Food Science and Biotechnology, vol. 24, no. 2, pp. 601-606, 2015.

[40] A. H. Ibrahim, "Effects of exopolysaccharide-producing starter cultures on physicochemical, rheological and sensory properties of fermented camel's milk," Emirates Journal of Food and Agriculture, vol. 27, no. 4, pp. 374-383, 2015.

[41] S. A. Ibrahem and I. E. M. El Zubeir, "Processing, composition and sensory characteristic of yoghurt made from camel milk and camel-sheep milk mixtures," Small Ruminant Research, vol. 136, pp. 109-112, 2016.

[42] U. S. Dubey, M. Lal, A. Mittal, and S. Kapur, "Therapeutic potential of camel milk," Emirates Journal of Food and Agriculture, vol. 28, no. 3, pp. 164-176, 2016.

[43] A. G. M. Abdel Gader and A. A. Alhaider, "The unique medicinal properties of camel products: A review of the scientific evidence," Journal of Taibah University Medical Sciences, vol. 11, no. 2, pp. 98-103, 2016.

[44] T. Mihic, D. Rainkie, K. J. Wilby, and S. A. Pawluk, "The Therapeutic Effects of Camel Milk: A Systematic Review of Animal and Human Trials," Journal of Evidence-Based Complementary and Alternative Medicine, vol. 21, no. 4, pp. NP110-NP126, 2016.

[45] A. K. Yadav, R. Kumar, L. Priyadarshini, and J. Singh, "Composition and medicinal properties of camel milk: a review," Asian Journal of Dairy and Food Research, vol. 34, no. 2, p. 83, 2015.

[46] R. P. Agrawal, S. Jain, S. Shah, A. Chopra, and V. Agarwal, "Effect of camel milk on glycemic control and insulin requirement in patients with type 1 diabetes: 2-years randomized controlled trial," European Journal of Clinical Nutrition, vol. 65, no. 9, pp. 1048-1052, 2011.
[47] R. H. Mohamad, Z. K. Zekry, and H. A. Al-Mehdar, "Camel milk as an adjuvant therapy for the treatment of type 1 diabetes: verification of a traditional ethnomedical practice," Journal of Medicinal Food, vol. 12, no. 2, pp. 461-465, 2009.

[48] R. P. Agrawal, S. Budania, P. Sharma et al., "Zero prevalence of diabetes in camel milk consuming Raica community of northwest Rajasthan, India," Diabetes Research and Clinical Practice, vol. 76, no. 2, pp. 290-296, 2007.

[49] A. B. Shori, "Camel milk as a potential therapy for controlling diabetes and its complications: A review of in vivo studies," Journal of Food and Drug Analysis, vol. 23, no. 4, pp. 609-618, 2015.

[50] R. P. Agrawal, R. Beniwal, D. K. Kochar et al., "Camel milk as an adjunct to insulin therapy improves long-term glycemic control and reduction in doses of insulin in patients with type1 diabetes: A 1 year randomized controlled trial [1]," Diabetes Research and Clinical Practice, vol. 68, no. 2, pp. 176-177, 2005.

[51] O. U. Beg, H. Von Bahr-Lindstrom, Z. H. Zaidi, and H. Jornvall, "A camel milk whey protein rich in half-cystine. Primary structure, assessment of variations, internal repeat patterns, and relationships with neurophysin and other active polypeptides," European Journal of Biochemistry, vol. 159, no. 1, pp. 195-201, 1986.

[52] A. O. Abdulrahman, M. A. Ismael, K. Al-Hosaini et al., "Differential effects of camel milk on insulin receptor signaling Toward understanding the insulin-like properties of camel milk," Frontiers in Endocrinology, vol. 7, article no. 4, 2016.

[53] E. I. Elagamy, "Effect of heat treatment on camel milk proteins with respect to antimicrobial factors: A comparison with cows' and buffalo milk proteins," Food Chemistry, vol. 68, no. 2, pp. 227-232, 2000.

[54] G. Konuspayeva, B. Faye, G. Loiseau, and D. Levieux, "Lactoferrin and immunoglobulin contents in camel's milk (Camelus bactrianus, Campus dromedarius, and Hybrids) from Kazakhstan," Journal of Dairy Science, vol. 90, no. 1, pp. 38-46, 2007.

[55] E. M. El-Fakharany, L. Sánchez, H. A. Al-Mehdar, and E. M. Redwan, "Effectiveness of human, camel, bovine and sheep lactoferrin on the hepatitis $C$ virus cellular infectivity: Comparison study," Virology Journal, vol. 10, article no. 199, 2013.

[56] E.-R. M. Redwan and A. Tabll, "Camel lactoferrin markedly inhibits hepatitis $\mathrm{C}$ virus genotype 4 infection of human peripheral blood leukocytes," Journal of Immunoassay and Immunochemistry, vol. 28, no. 3, pp. 267-277, 2007.

[57] E. M. Redwan, E. M. EL-Fakharany, V. N. Uversky, and M. H. Linjawi, "Screening the anti infectivity potentials of native Nand C-lobes derived from the camel lactoferrin against hepatitis C virus," BMC Complementary and Alternative Medicine, vol. 14, no. 1, article no. 219, 2014.

[58] E. M. Redwan, H. A. Almehdar, E. M. El-Fakharany, A.-W. K. Baig, and V. N. Uversky, "Potential antiviral activities of camel, bovine, and human lactoperoxidases against hepatitis $\mathrm{C}$ virus genotype 4," RSC Advances, vol. 5, no. 74, pp. 60441-60452, 2015.

[59] H. M. Korashy, Z. H. Maayah, A. R. Abd-Allah, A. O. S. El-Kadi, and A. A. Alhaider, "Camel milk triggers apoptotic signaling pathways in human hepatoma HepG2 and breast cancer MCF7 cell lines through transcriptional mechanism," Journal of Biomedicine and Biotechnology, vol. 2012, Article ID 593195, 9 pages, 2012.

[60] L. Y. Al-Ayadhi and N. E. Elamin, "Camel milk as a potential therapy as an antioxidant in autism spectrum disorder (ASD)," Evidence-Based Complementary and Alternative Medicine, vol. 2013, Article ID 602834, 8 pages, 2013. 
[61] S. Bashir and L. Y. Al-Ayadhi, "Effect of camel milk on thymus and activation-regulated chemokine in autistic children: double-blind study," Pediatric Research, vol. 75, no. 4, pp. 559563,2014

[62] H. Korhonen and A. Pihlanto, "Bioactive peptides: production and functionality," International Dairy Journal, vol. 16, no. 9, pp. 945-960, 2006.

[63] S. Le Maux, A. B. Nongonierma, B. Murray, P. M. Kelly, and R. J. FitzGerald, "Identification of short peptide sequences in the nanofiltration permeate of a bioactive whey protein hydrolysate," Food Research International, vol. 77, pp. 534-539, 2015.

[64] V. Đorđević, B. Balanč, A. Belščak-Cvitanović et al., “Trends in encapsulation technologies for delivery of food bioactive compounds," Food Engineering Reviews, vol. 7, no. 4, pp. 452490, 2015.

[65] Q. Liu, A. K. Raina, M. A. Smith, L. M. Sayre, and G. Perry, "Hydroxynonenal, toxic carbonyls, and Alzheimer disease," Molecular Aspects of Medicine, vol. 24, no. 4-5, pp. 305-313, 2003.

[66] S. R. J. Maxwell and G. Y. H. Lip, "Free radicals and antioxidants in cardiovascular disease," British Journal of Clinical Pharmacology, vol. 44, no. 4, pp. 307-317, 1997.

[67] F. K. Salawu, J. T. Umar, and A. B. Olokoba, "Alzheimers disease: A review of recent developments," Annals of African Medicine, vol. 10, no. 2, pp. 73-79, 2011.

[68] B. Halliwell, "Role of free radicals in the neurodegenerative diseases: therapeutic implications for antioxidant treatment," Drugs and Aging, vol. 18, no. 9, pp. 685-716, 2001.

[69] A. Pihlanto, "Antioxidative peptides derived from milk proteins," International Dairy Journal, vol. 16, no. 11, pp. 1306-1314, 2006.

[70] H. El Hatmi, Z. Jrad, T. Khorchani et al., "Identification of bioactive peptides derived from caseins, glycosylation-dependent cell adhesion molecule-1 (GlyCAM-1), and peptidoglycan recognition protein-1 (PGRP-1) in fermented camel milk," International Dairy Journal, vol. 56, pp. 159-168, 2016.

[71] M. Homayouni-Tabrizi, H. Shabestarin, A. Asoodeh, and M. Soltani, "Identification of Two Novel Antioxidant Peptides from Camel Milk Using Digestive Proteases: Impact on Expression Gene of Superoxide Dismutase (SOD) in Hepatocellular Carcinoma Cell Line," International Journal of Peptide Research and Therapeutics, vol. 22, no. 2, pp. 187-195, 2016.

[72] M. Moslehishad, M. R. Ehsani, M. Salami et al., "The comparative assessment of ACE-inhibitory and antioxidant activities of peptide fractions obtained from fermented camel and bovine milk by Lactobacillus rhamnosus PTCC 1637," International Dairy Journal, vol. 29, no. 2, pp. 82-87, 2013.

[73] Z. Jrad, J.-M. Girardet, I. Adt et al., "Antioxidant activity of camel milk casein before and after in vitro simulated enzymatic digestion," Mljekarstvo, vol. 64, no. 4, pp. 287-294, 2014.

[74] M. Rahimi, S. M. Ghaffari, M. Salami et al., "ACE- inhibitory and radical scavenging activities of bioactive peptides obtained from camel milk casein hydrolysis with proteinase K," Dairy Science and Technology, vol. 96, no. 4, pp. 489-499, 2016.

[75] M. Salami, A. A. Moosavi-Movahedi, F. Moosavi-Movahedi et al., "Biological activity of camel milk casein following enzymatic digestion," Journal of Dairy Research, vol. 78, no. 4, pp. 471-478, 2011.

[76] M. Salami, R. Yousefi, M. R. Ehsani et al., "Enzymatic digestion and antioxidant activity of the native and molten globule states of camel $\alpha$-lactalbumin: Possible significance for use in infant formula," International Dairy Journal, vol. 19, no. 9, pp. 518-523, 2009.

[77] M. Salami, A. A. Moosavi-Movahedi, M. R. Ehsani et al., "Improvement of the antimicrobial and antioxidant activities of camel and bovine whey proteins by limited proteolysis," Journal of Agricultural and Food Chemistry, vol. 58, no. 6, pp. 3297-3302, 2010.

[78] J. Rytkönen, T. J. Karttunen, R. Karttunen et al., "Effect of heat denaturation on beta-lactoglobulin-induced gastrointestinal sensitization in rats: Denatured $\beta$ LG induces a more intensive local immunologic response than native $\beta \mathrm{LG}$," Pediatric Allergy and Immunology, vol. 13, no. 4, pp. 269-277, 2002.

[79] I. Sélo, G. Clément, H. Bernard et al., "Allergy to bovine $\beta$ lactoglobulin: Specificity of human IgE to tryptic peptides," Clinical and Experimental Allergy, vol. 29, no. 8, pp. 1055-1063, 1999.

[80] E. I. El-Agamy, M. Nawar, S. M. Shamsia, S. Awad, and G. F. W. Haenlein, "Are camel milk proteins convenient to the nutrition of cow milk allergic children?" Small Ruminant Research, vol. 82, no. 1, pp. 1-6, 2009.

[81] A. Ametani, T. Sakurai, Y. Katakura et al., "Amino acid residue substitution at $\mathrm{t}$-cell determinant-flanking sites in $\beta$-lactoglobulin modulates antigen presentation to t cells through subtle conformational change," Bioscience, Biotechnology and Biochemistry, vol. 67, no. 7, pp. 1507-1514, 2003.

[82] C. Bevilacqua, P. Martin, C. Candalh et al., "Goats' milk of defective $\alpha$ s1-casein genotype decreases intestinal and systemic sensitization to $\beta$-lactoglobulin in guinea pigs," Journal of Dairy Research, vol. 68, no. 2, pp. 217-227, 2001.

[83] E. I. El-Agamy, "The challenge of cow milk protein allergy," Small Ruminant Research, vol. 68, no. 1-2, pp. 64-72, 2007.

[84] P. Restani, A. Gaiaschi, A. Plebani et al., "Cross-reactivity between milk proteins from different animal species," Clinical and Experimental Allergy, vol. 29, no. 7, pp. 997-1004, 1999.

[85] E. Seifu, "Handling, preservation and utilization of camel milk and camel milk products in Shinile and Jijiga Zones, eastern Ethiopia," Livestock Research for Rural Development, vol. 19, no. 6, 2007.

[86] A. M. El-Hadi Sulieman, A. A. Ilayan, and A. El-Awad El Faki, "Chemical and microbiological quality of Garris, Sudanese fermented camel's milk product," International Journal of Food Science and Technology, vol. 41, no. 3, pp. 321-328, 2006.

[87] K. Maurad and K.-H. Meriem, "Probiotic characteristics of Lactobacillus plantarum strains from traditional butter made from camel milk in arid regions (Sahara) of Algeria," Grasas y Aceites, vol. 59, no. 3, pp. 218-224, 2008.

[88] S. Takeda, K. Yamasaki, M. Takeshita et al., “The investigation of probiotic potential of lactic acid bacteria isolated from traditional Mongolian dairy products," Animal Science Journal, vol. 82, no. 4, pp. 571-579, 2011. 

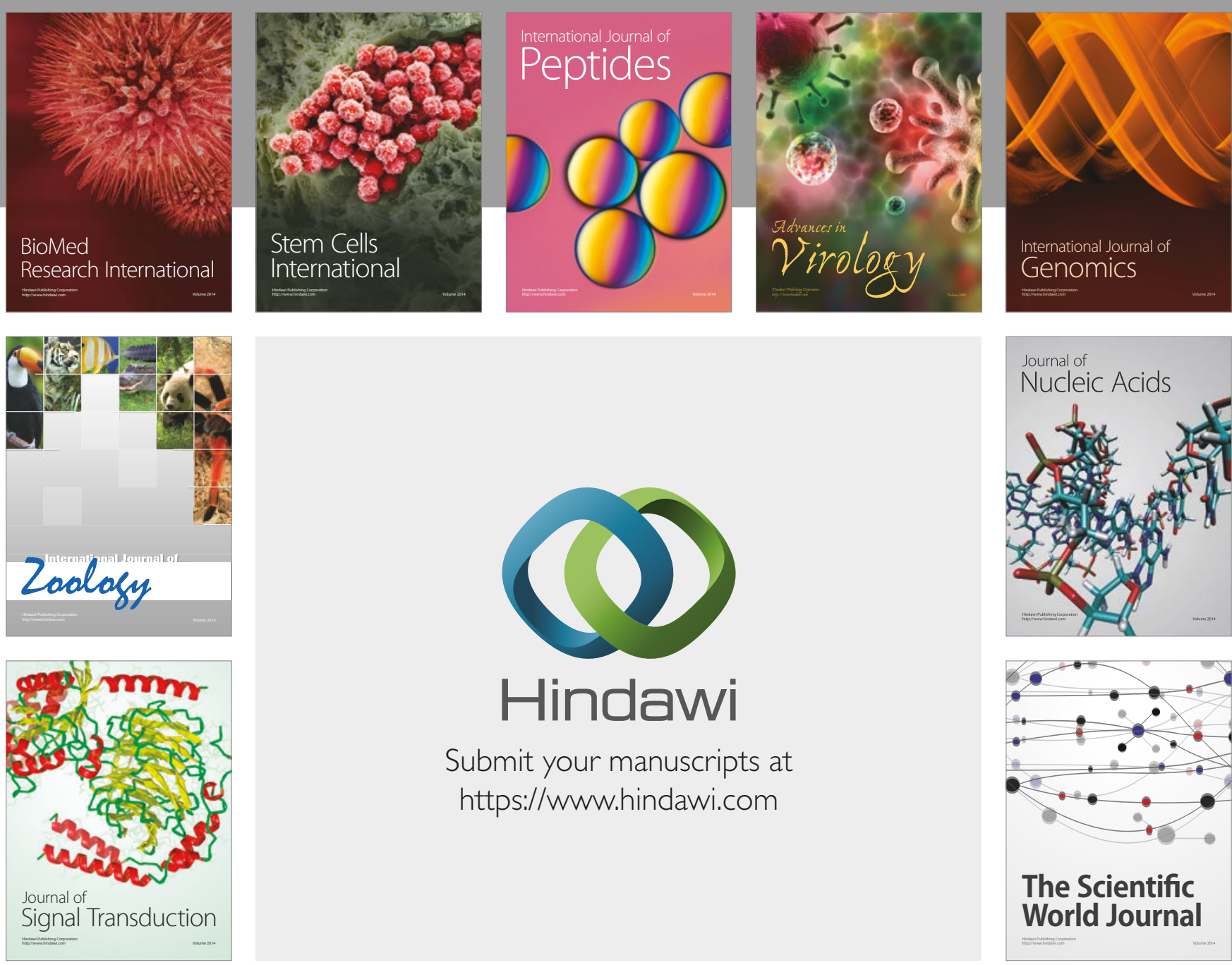

Submit your manuscripts at

https://www.hindawi.com
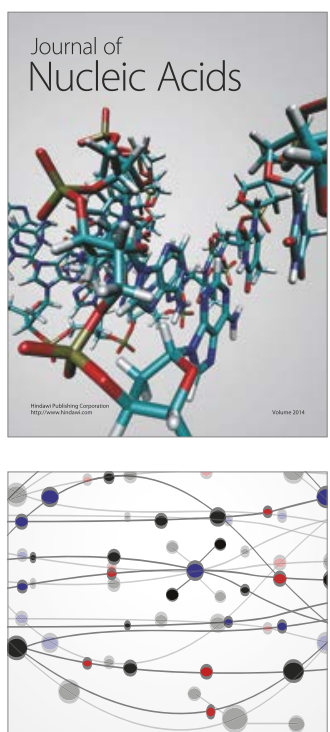

The Scientific World Journal

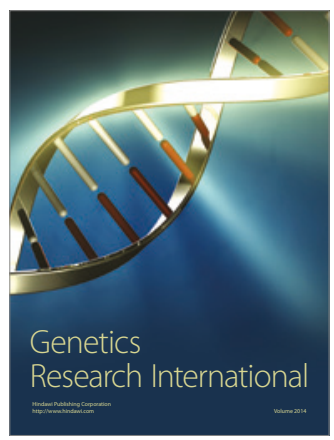

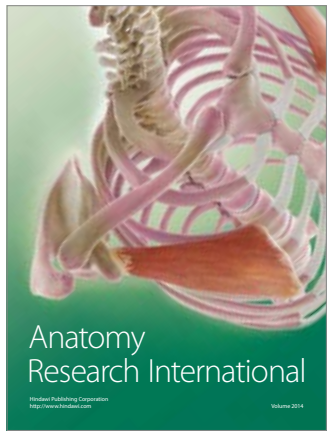

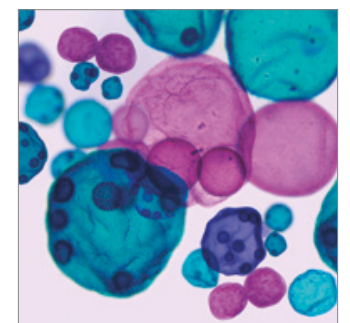

International Journal of Microbiology
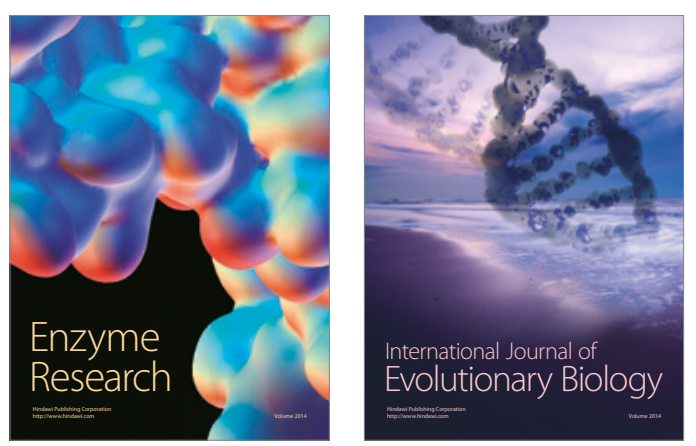
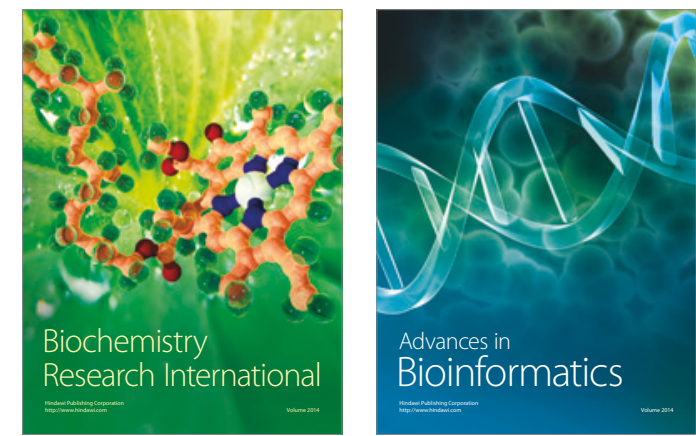

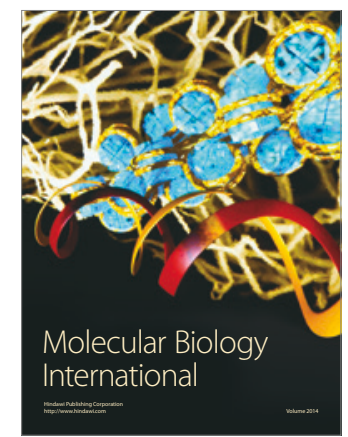

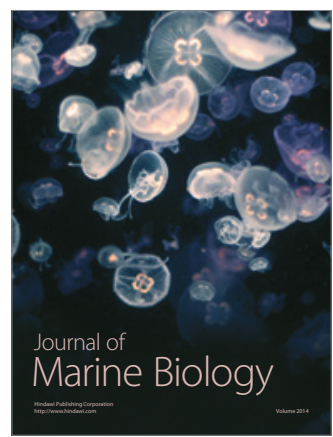

